Original Research Paper

\title{
EVALUATION OF EFFECTIVENESS OF MORINGA'S LEAVES AGAINST Escherichia coli USING DISC DIFFUSION METHOD
}

\author{
Erin Dhillon*, Margaretia Yenni Rotua, Adrian Khu, Ade Sinaga
}

\author{
Faculty of Medicine, Universitas Prima Indonesia, Medan, Indonesia
}

\section{Email Corresponding: \\ erindhillon@yahoo.com}

Page : $41-46$

\section{Keywords:}

Moringa leaves,

etanol,

disc diffusion,

Eschrichia coli

\section{Kata Kunci :}

Daun kelor,

etanol,

difusi cakram,

Escherichia coli

\section{Published by:}

Tadulako University,

Managed by Faculty of Medicine.

Email: healthytadulako@gmail.com

Phone (WA): +6285242303103

Address:

Jalan Soekarno Hatta Km. 9. City of

Palu, Central Sulawesi, Indonesia
The UPTD Puskesmas annual report book in Medan Tembung District reported that the number of diarrhea sufferers had increased every year. Moringa plants have many benefits, both leaves, flowers, stems, fruit blossoms, and seeds. The moringa leaves contain various phytochemicals, viz. alkaloids, flavonoids, phenols, steroids, triterpenoids, and tannins, which have antimicrobial properties. This study aimed to determine the antimicrobial effect of the ethanol extract of Moringa leaves against Escherichia coli. This study was an experimental study with a posttest only control group design model. The method used to evaluate ethanol extract's anti-bacterial effect from Moringa leaves was the disc diffusion method. Moringa leaf extract was obtained by maceration method with a ratio of Simplicia powder, and ethanol solvent was 1:10. The ethanol extract was then concentrated by rotary evaporator and diluted using DMSO into five different concentrations viz. 70\%, 75\%, 85\%, 90\%, and 95\%. All data were analyzed by the One Way Anova test and expressed as Mean $\pm S D$. This study showed that all treatment groups in this study had a significant difference in the zone of inhibition; it was shown by the P-value $<0.05$. Only $70 \%$ of concentrations from Serial concentration of extract were significant differences against the positive control. Overall, it can be concluded that the ethanol extract of moringa leaves is effective as an anti-bacteria against Escherichia coli, especially at concentrations $>75 \%$.

ABSTRAK

Data dari buku laporan tahunan UPTD Puskesmas di Kecamatan Medan Tembung dilaporkan bahwa jumlah penderita diare mengalami peningkatan dari tahun ke tahun. Tanaman kelor memiliki banyak manfaat baik daun, bunga, batang, bunga buah, maupun bijinya. Bagian daun dari tanaman kelor mengandung berbagai kandungan fitokimia berupa senyawa alkaloida, flavonoida, fenol, steroida/triterpenoida, tanin yang sebagian besar dapat berupa anti bakteri dan anti mikroba. Penelitian ini bertujuan untuk mengetahui efek antimikroba dari ekstrak etanol daun kelor terhadap bakteri Esherichia coli. Penelitian ini merupakan penelitian eksperimental dengan pendekatan posttest only control group design. Metode yang digunakan untuk menguji efek antibakteri dari ekstrak etaol daun kelor adalah metode difusi cakram. Ekstrak daun kelor diperoleh dengan metode maserasi denga perbandingan serbuk simplisia dan pelarut etanol adalah 1:10. Kemudian, ekstrak etanol tersebut dipekatan dengan menggunakan rotary evaporator dan diencerkan dengan menggunaan DMSO menjadi 5 konsenrasi berbeda yaitu 70\%, 75\%, 85\%, 90\%, dan 95\%. Data penelitian ini dianalis dengan menggunakan uji One Way Anova dan ditampilkan dalma bentuk Mean \pm SD. Hhasil Penelitian ini menunjukkan bahwa seluruh kelompok perlakuan pada penelitian ini dijumpai perbedaan yang signifian terhadap diameter zona hambat yang terbentuk, hal ini terlihat dari nilai $\mathrm{P}<0.05$. Dari seluruh konsnetrasi ekstrak yang diuji hanya konsentrasi $70 \%$ yang dijumpai perbedaan yang signifian terhadap kontrol positive. Sehingga dapat disimpulkan bahwa ekstrak etanol daun kelor efektif sebagai antibatkeri terhadap Esherichia coli terutam pada dosis $>75 \%$. 


\section{INTRODUCTION}

For a long time ago, traditional medicine has been used over the world. The usage of traditional medicine from generation to generation has been kept as a cultural heritage. The utility of traditional medicine has been created and developed from country to country like China, Egyptian, Indian, Greek, roman, and Slav. World Health Organization (WHO) has reported whether around $80 \%$ of world people used traditional medicine to maintain the health condition. Several studies have been proved that Indonesia had rapidly developed various herbal as ingredients of traditional medicine. Most of these plant has been utilized over the world. Hence, it has been obvious that Indonesia was enriched by various herbal. ${ }^{1-4}$ Although various natural resources enrich Indonesia as herbal that is utilized in daily life. However, the appropriate dosage is required. Even though it was herbal, inappropriate dosage may lead to a bad effect on the body. ${ }^{5}$

Moringa plant is one of the plant types that easily grow in tropical areas such as Indonesia and subtropical areas. This plant has various names based on the region like kelor (Jawa, Sunda, Bali, Lampung), maronggih (Madura), ongge (Bima), and murong or barunggai (Sumatera). Moringa is widely used as nutritious and alternative food over the world. All part of Moringa like leaves, flower, stem, fruit, and the seed has many health benefits. However, the moringa's leaves the most valuable part. Hence it is also known as Mother's Bestfriend or Miracle Tree. ${ }^{67}$ The active content of moringa's leaves as the secondary metabolite responsible for the health benefit from this plant. These secondary metabolites include alkaloid, flavonoid, phenol, steroid/ triterpenoid, and tannin. Alkaloid and flavonoid in moringa leave responsible for antimicrobial properties. Alkaloid will destroy peptidoglycan in the bacterial wall and lead to bacterial cell death.
Meanwhile, flavonoids will interact with bacterial DNA and interrupt bacterial cell wall, microsomal, and lysosome permeability. 1,8

Due to moringa's leaves has antimicrobial activity. It becomes important to utilize this property while the number of bacterial infections is high. Escherichia coli infects humans by contaminating food or beverage like raw meat or vegetable. Moreover, this bacteria will contaminate and colonies human's intestine. After that, this bacteria causes acute gastrointestinal disease like diarrhea and disseminated into urinary tract infection, meningitis, and peritonitis. 9 . Based on the Data from Medan Tembung District, the number of diarrhea was 467 people in 2016, 356 people in 2017, and 820 people in 2018, which means the number of diarrhea was increased every year.

Based on the fact above, it becomes important to explore the anti-bacterial effect of moringa's leaves against Escherichia coli while the number of Escherichia coli is high. Hence, a recent study was aimed to evaluate the anti-bacterial effect of moringa's leaves against Escherichia coli.

\section{METHODS}

This study was an experimental study with the post-test-only control group design in Mei-July 2020 at Microbiology Laboratory of Universitas Prima Indonesia. This study was used moringa's leaves from a traditional market in Medan Helvetia District. Meanwhile, Escherichia coli was obtained from slop agar that has been cultured in the Microbiology Laboratory from Pharmacy Faculty of North Sumatera University.

Other materials that were also used in this study were aquadest, 96\% ethanol, ciprofloxacin as standard, Nutrient Agar (NA), Nutrient Broth (NB), Normal Saline, DMSO (Dimethyl Sulfide Oxide), Whatman Filter 
Paper no. 1, and reagent for phytochemical screening.

Moringa's leaves were collected and then cleaned and washed with water until clean. Furthermore, moringa's leaves were dried. A blender mashed the simplicia until it becomes a powder. The powder was sieved by 60 mesh sieve until a fine powder was obtained, and it was known as simplicia powder.

Amount of 200 grams of simplicia powder into the Erlenmeyer, then soaked in $500 \mathrm{ml}$ of $96 \%$ ethanol solution, covered with aluminum foil, and left for five days, stirring occasionally. After five days, it was filtered by filter paper. The residue was repeated to add $250 \mathrm{ml}$ of $96 \%$ ethanol solution and left for two days while stirring occasionally. After two days, the sample is filtered again to produce. The filtrate from the first maceration and remaceration was collected, then it was evaporated using a rotary evaporator to obtain the concentrated form of moringa's leaves extract.

The extract was screened phytochemical contents included alkaloid, tannin, saponin, flavonoid, triterpenoid/ steroid, glycoside, and polyphenol. Moreover, the concentrated form of moringa's leaves extract was dissolved into some concentrations by DMSO. The amount of 7 grams, 7.5 grams, 8.5 grams, 9.0 grams, and 9.5 grams of the extract was dissolved by $10 \mathrm{ml}$ of DMSO using volumetric flask into $70 \%, 75 \%, 85 \%, 90 \%$, and $95 \%$, respectively.

Disc diffusion methods were performed in the anti-bacterial assay. Initially, NB and NA were prepared as suspension media for anti-bacterial assay. NB and NA were prepared according to manufacture instruction. NA was prepared by dissolving 2.8 grams of NA powder in $100 \mathrm{ml}$ of aquadest. Meanwhile, NB was made by dissolving 2.4 grams of NB in $100 \mathrm{ml}$ of aquadest. These media are homogenized by using a hot plate magnetic stirrer.
An amount of one bacterial inoculum was firstly suspended into NB and incubated for 24 hours. After that, an amount of one bacterial inoculum from the NB suspension was scratched on the NA surface on a petri dish. Then the disc paper that had been soaked in some concentrations of moringa's leaves extract, ciprofloxacin (standard), and DMSO (control) was placed on the NA surface, and the media was then incubated for 24 hours. After 24 hours, the width of the inhibition zone formed around the disc paper was measured.

All data in this study were analyzed using IBM SPSS 25. The width of the inhibition zone was expressed as Mean \pm SD. As a preliminary test, data normality analysis was performed by Shapiro-Wilk. If the data is normally distributed, One Way Anova was used as a hypothesis test instead of the Kruskal-Wallis test.

\section{RESULT}

The following table showed the result of phytochemical screening against the extract of moringa's leaves.

Table 1. Phytochemical Screening of Moringa's Leaves extract

\begin{tabular}{ccc}
\hline Phytochemicals & Reagent & Results \\
\hline & Meyer & + \\
Alkaloid & Dragendroff & + \\
& Bouchart & + \\
Tanin & $\mathrm{FeCl}_{3} 10 \%$ & + \\
Saponin & HCL 2N & + \\
& Concentrated & \\
Flavonoid & HCL $+\mathrm{Mg}$ & + \\
& Powder & \\
Triterpen/ & Lieberman - & + \\
steroid & burchat & \\
Glycone & LP molish & - \\
& Lieberman & - \\
Aglycone & Burchad & \\
Anthraquinone & $\mathrm{CCl}_{4}+$ & - \\
glycoside & $\mathrm{Ammonia}$ & + \\
Polyphenols & $\mathrm{FeCl}_{3} 1 \%$ & + \\
\hline
\end{tabular}


Based on the table above, it can be seen that moringa's leaves extract contains phytochemicals in the form of alkaloids, tannins, saponins, flavonoids, triterpenes / steroids, and polyphenols.

Meanwhile, the result of the antimicrobial assay of moringa's leaves was shown by the following figure.

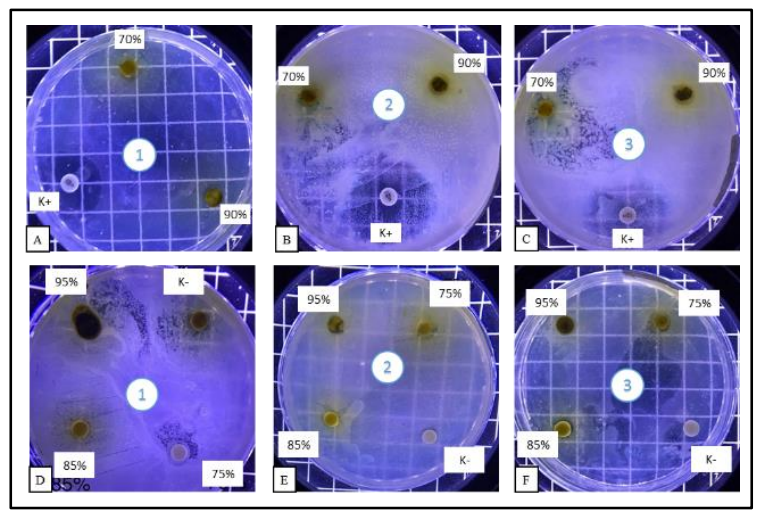

Figure 1. Inhibition Zone in The Disc Diffusion Assay from Various Extract of Moringa's Leaves Extract, Standard, and Control

Based on the figure above, it can be seen that the inhibition zone formed at each concentration, standard, and control group. Figures $\mathrm{A}$ to $\mathrm{C}$ showed the inhibition zone at concentrations of $70 \%$ and $90 \%$ and standard on three repetitions. Meanwhile, figures D to $\mathrm{F}$ showed the inhibition zone at concentrations of $75 \%, 85 \%$, and $95 \%$ and control on three repetitions.

Moreover, these inhibition zones were measured by calipers in millimeters $(\mathrm{mm})$. Moreover, these data were analyzed by the Shapiro-Wilk test. The result of the analysis was shown in the following table.

\section{Table 2. Shapiro-Wilk Analysis for} Normality Test

\begin{tabular}{ccc}
\hline Treatment & P-Value & Interpretation \\
\hline $70 \%$ & 0.843 & Data was Normal \\
$75 \%$ & 1.000 & Data was Normal \\
$85 \%$ & 0.780 & Data was Normal \\
$90 \%$ & 0.817 & Data was Normal \\
$95 \%$ & 0.463 & Data was Normal \\
Standard & 0.132 & Data was Normal \\
\hline
\end{tabular}

Based on the table above, it can be seen that all data was normal. Hence, the hypothesis test in this study was one way ANOVA. After that, the data was analyzed by the Levene test to look for homogeneity. The result of the Levene test whether P-Value was lower than 0.05 , it means homogeneity of data was homogenous. Furthermore, the following table shows the result of the one-way ANOVA and Post Hoc Test Games-Howell analysis.

Table 3. Comparison of Antimicrobial Activity among Various Concentration of Moringa's Leaves, Standard, and Control Groups

\begin{tabular}{|c|c|c|}
\hline Treatment & $\begin{array}{c}\text { Width of } \\
\text { Inhibition Zone, } \\
\text { mm } \\
\text { (Mean } \pm \text { SD) }\end{array}$ & P-Value \\
\hline $70 \%{ }^{a b}$ & $7.97 \pm 0.35$ & $<0.05$ \\
\hline $75 \%^{b}$ & $8.70 \pm 0.10$ & \\
\hline $85 \%^{b}$ & $9.63 \pm 0.25$ & \\
\hline $90 \%^{b}$ & $11.43 \pm 1.21$ & \\
\hline $95 \%^{\mathrm{b}}$ & $11.83 \pm 0.21$ & \\
\hline Standar ${ }^{\mathbf{d}}$ & $26.43 \pm 3.62$ & \\
\hline Control & $6.00 \pm 0.00$ & \\
\hline
\end{tabular}

a there is a significant difference against standard; ${ }^{b}$ there is a significant difference against control

Based on the table above, it can be seen that there was a significant difference between the width of the inhibition zone among each concentration of moringa's leaves extract used. It was shown by P-value <0.05. Meanwhile, the post hoc games-Howell test showed that the smallest concentration (70\%) showed a significant difference between standard and higher concentrations. Moreover, the higher concentration only showed significant differences against control. 


\section{DISCUSSION}

It was obvious that the result of this study has answered the purpose of this study. The lowest concentration (70\%) showed less antimicrobial effect than the standard. However, the antimicrobial activity was still better than control. Interestingly, at higher concentrations $(\geq 75 \%$ ), the antimicrobial activity was still sufficiently effective as well as standard.

The anti-bacterial activity of moringa's leaves extracts at a concentration of $70 \%-85 \%$ is weak, while at a concentration $>85 \%$, it is quite potent. This classification of antibacterial activity can be seen in the table below. ${ }^{10}$

Table 4. Greenwood Classification for Antimicrobial Activity

\begin{tabular}{cc}
\hline $\begin{array}{c}\text { Width of Inhibition } \\
\text { Zone }\end{array}$ & $\begin{array}{c}\text { Diameter Zona } \\
\text { Hambat }\end{array}$ \\
\hline $20 \mathrm{~mm}$ & Very Potent \\
$16-20 \mathrm{~mm}$ & Potent \\
$10-15 \mathrm{~mm}$ & Quietly Potent \\
$<10 \mathrm{~mm}$ & Weak \\
\hline
\end{tabular}

Previous studies have also reported a similar result against this study. Moodley et al. (2018) reported that the nanoparticles from moringa's leave extract had antimicrobial activity against various microbes, both in fungi and bacteria. One of them is the Escherichia coli that has a MIC of more than $12.5 \mu \mathrm{g} / \mathrm{ml}$. Additionally, Pal et al. (2018) also reported that the nanoparticles from moringa's leave extract also had an antibacterial effect against Escherichia coli with an inhibition zone diameter of $3.3 \mathrm{~cm}$. Interestingly, these studies show that moringa's leave extract's anti-bacterial effect was more effective on gram-negative than gram-positive bacteria ${ }^{11,12}$.

The moringa leaves' anti-bacterial activity may be due to tannin, flavonoid, alkaloid, and polyphenol as the secondary metabolite. Alkaloid will destroy peptidoglycan in the bacterial wall and lead to bacterial cell death. Meanwhile, flavonoids will interact with bacterial DNA and interrupt the bacterial cell wall's permeability, microsomal, and lysosome. ${ }^{1,8} 13$

On the other hand, moringa's leaves extract also contains lectin. Lectin is an anionic protein with a molecular weight of 60 $\mathrm{kDa}$ composed of monomers with a molecular weight of $5 \mathrm{kDa}$. Lectin is active after heating at a temperature of $100^{\circ} \mathrm{C}$ and is stable at a $\mathrm{pH}$ of 4.5-9.5. This bacteriostatic and bactericidal effect is due to the anti-biofilm properties of lectin. Lectins interact with glycocalyx and polysaccharide molecules on the cell surface. Subsequently, the lectins will reduce the interaction between bacterial cells, preventing eco-copolymerization with the extracellular matrix. It will lead to damage to bacterial cell walls and disrupt the formation of biofilms from bacteria. Another mechanism that also plays a role in the anti-bacterial activity of the lectins on moringa leaves is the anti-quorum sensing effect, which prevents the expression of genes responsible for forming biofilms and various other virulence factors. ${ }^{14}$.

\section{CONCLUSION}

It can be concluded that the effective concentration of moringa's leaves extract as antibacterial against Escherichia coli was up to $75 \%$, which was as good as the standard (ciprofloxacin).

\section{ACKNOWLEDGMENT}

The author is very grateful to All Parties who have helped in this research.

\section{REFERENCES}

1. Dwika W, Putra P, Agung A, Oka Dharmayudha G, Sudimartini LM. Identifikasi Senyawa Kimia Ekstrak Etanol Daun Kelor (Moringa oleifera L) di Bali. Indones Med Veterinus Oktober. 2016;5(5):464-473.

2. Šantić Ž, Pravdić N, Bevanda M, Galić K. The historical use of medicinal plants in 
traditional and scientific medicine. Psychiatr Danub. 2017;4(4):787-792.

3. Sarad S, Sharma A, Kumar N. Distribution, Diversity, Indigenous Use and its Utilization of the Ethno medicinal Flora of Rajouri District, J \&K, India. Int $J$ Life-Sciences Sci Res. Published online 2017. doi:10.21276/ijlssr.2017.3.1.12

4. Jennifer H, Saptutyningsih E. Preferensi Individu Terhadap Pengobatan Tradisional Di Indonesia. Vol 16.; 2015.

5. Diantoro A, Rohman M, Budiarti R, Palupi HT, Pertanian F, Yudharta U. Pengaruh Penambahan Ekstrak Daun Kelor (Moringa Oleifera L.) Terhadap Kualitas Yoghurt. Teknol Pangan Media Inf dan Komun Ilm Teknol Pertan. 2015;6(2). doi:10.35891/tp.v6i2.469

6. Aminah S, Ramdhan $\mathrm{T}$, Yanis $\mathrm{M}$. Syarifah Am inah et. al. : Kandungan Nut risi dan Sifat Fungsional Tanam an Kelor ( M oringa oleifera ). Bul Pertan Perkota. 2015;5(30):35-44.

7. Salim R, Eliyarti E. Aktivitas Antioksidan Infusa Daun Kelor (Moringa Oleifera Lam.) Terhadap Warna Daun. $J$ Katalisator. 2019;4(2):91. doi:10.22216/jk.v4i2.4210

8. LRH Dima L, Astuty Lolo W. Uji Aktivitas Antibakteri Ekstrakk Daun Kelor (Moringa Oleifera L.) Terhadap Bakteri Escherichia Coli Dan Staphylococcus Aureus. Vol 5.; 2016.

9. Simanjuntak BM., Hasan W, Naria E. Tingkat Hygiene dan Kandungan Escherichia coli pada Air Tebu yang Dijual Sekitar Kota Medan. J Kesehat. 2018;9(2):214. doi:10.26630/jk.v9i2.818

10. Suandy, Girsang E, Nasution AN, Lister INE. Analysis of Protein Content, Spectrophotometry FT-IR, and Antibacterial Effects of Earthworm (Eudriluseugenia). Am Sci Res J Eng Technol Sci. 2020;63(1):94-101.

11. Moodley JS, Krishna SBN, Pillay K, Sershen, Govender P. Green synthesis of silver nanoparticles from Moringa oleifera leaf extracts and its antimicrobial potential. Adv Nat Sci Nanosci Nanotechnol. 2018;9(1):1-9. doi:10.1088/2043-6254/aaabb2
12. Pal S, Mondal S, Maity J, Mukherjee R. Synthesis and characterization of zno nanoparticles using Moringa Oleifera leaf extract: Investigation of photocatalytic and antibacterial activity. Int J Nanosci Nanotechnol. 2018;14(2):111-119.

13. Delelegn A, Sahile S, Husen A. Water purification and antibacterial efficacy of Moringa oleifera Lam. Agric Food Secur. 2018;7(25):1-10. doi:10.1186/s40066018-0177-1

14. Moura MC, Trentin DS, Napoleão TH, et al. Multi-effect of the water-soluble Moringa oleifera lectin against Serratia marcescens and Bacillus sp.: antibacterial, antibiofilm and anti-adhesive properties. $J$ Appl Microbiol. 2017;123(4):861-874. doi:10.1111/jam.13556 